\title{
PENGARUH PENGELOLAAN BARANG MILIK DAERAH TERHADAP KUALITAS LAPORAN KEUANGAN PEMERINTAH DAERAH KABUPATEN KEPULAUAN TALAUD
}

\author{
YULPI POAE ${ }^{1)}$ VENTJE ILAT ${ }^{2)}$ JESSY D.L. WARONGAN ${ }^{3)}$ \\ Program Studi Magister Akuntansi Fakultas Ekonomi dan bisnis Universitas Sam Ratulangi \\ E-mail: Yulpi.Poae@gmail.com
}

\begin{abstract}
This study is intended to analyze the influence of Regional-Owned Asset (BMD) management towards the quality of the financial statements of Talaud Local Government. The variables used in this study are planning, assessment, administration, and BMD surveillance and control. 158 respondents were taken by using purposive sampling method. This is a quantitative research with multiple regression analysis. The results show that the assessment, administration, surveillance and control of BMD partially significantly influence the quality of the financial statements of local government, while the planning has negative and insignificant influence to the quality of the financial statements of local government. The results also indicate that the planning, assessment, administration, surveillance and control of BMD simultaneously, positively and significantly influence the quality of the financial statements of Talaud Local Government. The value of the coefficient of determination shows that planning, assessment, administration, and surveillance and control of BMD influence simultaneously to the quality of financial statements of local government at $36.5 \%$, the balance $63.5 \%$ is influenced by other factors outside the research model.
\end{abstract}

Keywords: Quality of Financial Statements of Talaud Local Government, Planning, Assessment, Administration, BMD Surveillance and Control.

\begin{abstract}
Abstrak. Penelitian ini bertujuan untuk menganalisis pengaruh pengelolaan Barang Milik Daerah (BMD) terhadap kualitas laporan keuangan Pemerintah Daerah Kabupaten Kepulauan Talaud. Variabel-variabel yang digunakan adalah perencanaan, penilaian, penatausahaan, serta pengawasan dan pengendalian BMD. Dengan menggunakan metode purposive sampling, jumlah sampel penelitian yang diambil sebanyak 158 responden. Jenis penelitian ini adalah kuantitatif dengan menggunakan metode analisis regresi berganda. Hasil penelitian menunjukkan bahwa secara parsial penilaian, penatausahaan, pengawasan dan pengendalian BMD memiliki pengaruh positif dan signifikan terhadap kualitas laporan keuangan pemerintah daerah, sedangkan perencanaan BMD memiliki pengaruh negatif dan tidak signifikan terhadap kualitas laporan keuangan pemerintah daerah. Hasil pengujian secara simultan menunjukkan bahwa perencanaan, penilaian, penatausahaan, pengawasan dan pengendalian BMD berpengaruh positif dan signifikan terhadap kualitas laporan keuangan pemerintah daerah. Nilai dari koefisien determinasi menunjukkan bahwa perencanaan, penilaian, penatausahaan, pengawasan dan pengendalian BMD bersama-sama berkontribusi terhadap kualitas laporan keuangan pemerintah daerah yaitu sebesar $36,5 \%$, sisanya $63,5 \%$ dipengaruhi oleh faktor lain diluar model penelitian.
\end{abstract}

Kata Kunci: Kualitas LKPD, Perencanaan, Penilaian, Penatausahaan, Pengawasan dan Pengendalian BMD

\section{Pendahuluan}

Sistem pemerintahan daerah di Indonesia dewasa ini memasuki paradigma baru dimana salah satu tujuan dari penyelenggaraan pemerintah adalah terciptanya good governance dengan cara melakukan perubahan yang mendasar dalam mengelola daerah serta mengoptimalkan sumber daya yang dimiliki. Perubahan itu mengarah pada pelaksanaan desentralisasi atau otonomi daerah yang luas, nyata dan bertanggung jawab.

Pelaksanaan otonomi daerah sudah memasuki dua dasawarsa akan tetapi tujuan utama dari otonomi daerah belum terpenuhi secara signifikan terhadap peningkatan kesejahteraan masyarakat didaerah. Hal ini memunculkan berbagai fenomena dengan 
menguatnya tuntutan pelaksanaan akuntabilitas sektor publik terhadap pemerintah baik dipusat maupun daerah (Mardiasmo, 2009:20). Tuntutan tersebut terkait dengan perlu dilakukannya transparansi dan pemberian informasi kepada publik dalam rangka pemenuhan hak-hak publik.

Mahmudi (2015:4) menjelaskan bahwa penyusunan laporan keuangan pemerintah merupakan perwujudan dari akuntabilitas pengelolaan keuangan publik. Sehingga informasi dalam laporan keuangan harus mempunyai karakteristik kualitatif yaitu relevan, andal, dapat dibandingkan dan dapat dipahami.

Dalam praktek penyusunan laporan keuangan pemerintah daerah yang berkualitas, fenomena yang ada (kenyataan) masih berbeda dengan harapan. Berdasarkan hasil pemeriksaan Badan Pemeriksan Keuangan (BPK) didapati masih banyak laporan keuangan pemerintah daerah disusun belum berkualitas, karena belum menyajikan data-data keuangan yang sesuai dengan standar dan peraturan. Disamping itu juga, masih banyak penyimpangan-penyimpangan yang terjadi dan berhasil ditemukan dalam pelaksanaan audit atas laporan keuangan pemerintah daerah (Wungow, 2016). Hasil pemeriksaan terhadap laporan keuangan pemerintah daerah dari tahun 2010 sampai 2015, lima puluh lima persen (55\%) opini yang diberikan oleh BPK RI atas laporan keuangan pemerintah daerah adalah Wajar Dengan Pengecualian (Ihps BPK RI, 2015 sampai 2016).

Menurut Hidayati, et al. (2016), lemahnya pengelolaan Barang Milik Daerah (BMD) merupakan faktor yang menyebabkan masih banyaknya pemerintah daerah memperoleh opini Wajar Dengan Pengecualian. Bahkan pada kasus tertentu, ada daerah yang bahkan mengalami penurunan opini dari Wajar Tanpa Pengecualian (WTP) menjadi Wajar Dengan Pengecualian (WDP) atau Tidak Memberi Pendapat (TMP) yang disebabkan kekurangmampuan mewujudkan tata kelola aset/ barang pemerintah daerah secara baik (Ferdianus, 2013).

Pemerintah Kabupaten Kepulauan Talaud termasuk daerah yang masih berkutat dengan permasalahan aset/BMD. Hal ini terlihat dari opini yang diberikan oleh BPK atas laporan keuangan yang disajikan Pemerintah Kabupaten Kepulauan Talaud. Pada Tahun 2010, BPK memberikan opini Tidak Wajar (TW), Tahun 2011 memberikan opini Tidak Memberikan Pendapat (TMP), Tahun 2012 kembali memberikan opini Tidak Wajar (TW), Tahun 2013 Tidak Memberikan Pendapat (TMP), Tahun 2014 dan 2015 memberikan opini wajar sesuai dengan Standar Akuntansi Pemerintah, sedangkan pengecualian terletak pada pengelolaan aset/BMD.

Berdasarkan Peraturan Pemerintah Nomor 27 Tahun 2014, pengelolaan BMD adalah tidak sekedar administratif semata, tetapi lebih maju berfikir dalam menangani BMD, dengan meningkatkan efisiensi, efektifitas dan menciptakan nilai tambah dalam mengelola aset/BMD. Oleh karena itu, lingkup pengelolaan Barang Milik negara/daerah mencakup perencanaan kebutuhan dan penganggaran; pengadaan; penggunaan; pemanfaatan; pengamanan dan pemeliharaan; penilaian; pemindahtanganan; pemusnahan; penghapusan; penatausahaan; dan pembinaan, pengawasan dan pengendalian. Dengan pengelolaan BMD yang efisien dan efektif mulai dari perencanaan sampai dengan pengendaliannya diharapkan dapat menghindari penyimpangan dari peraturan yang berlaku terlebih pekerjaan yang dilaksanakan berjalan sesuai dengan rencana yang telah ditetapkan.

Berdasarkan pemikiran tersebut, beberapa hal yang menjadi fokus dalam tulisan ini adalah mencakup pengaruh pengelolaan BMD terhadap kualitas laporan keuangan Pemerintah Daerah Kabupaten Kepulauan Talaud, dengan Faktor-faktor pengelolaan BMD yang diteliti adalah faktor perencanaan, penilaian, penatausahaan, pengawasan dan pengendalian BMD, yang divisualisasikan dalam kerangka berpikir sebagaimana pada gambar 1. 


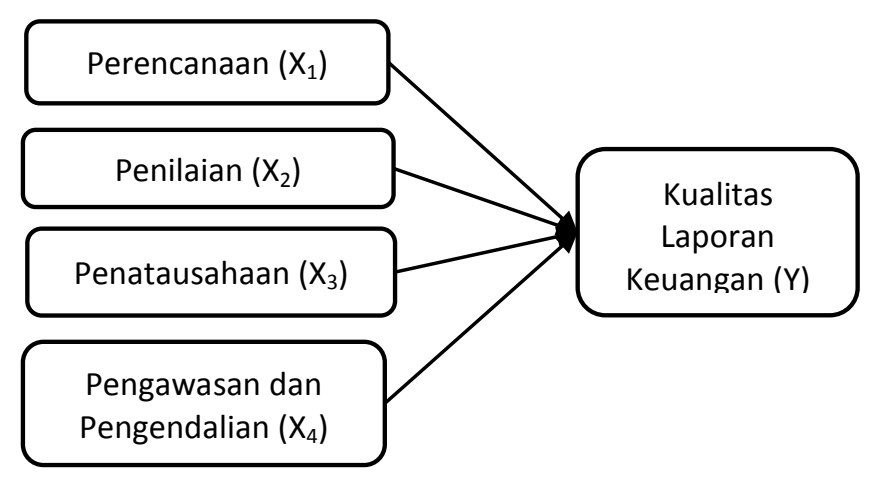

Gambar 1. Kerangka Pemikiran

Perencanaan BMD merupakan kegiatan merumuskan rincian kebutuhan BMD untuk menghubungkan pengadaan barang yang telah lalu dengan keadaan yang sedang berjalan sebagai dasar dalam melakukan tindakan pemenuhan kebutuhan yang akan datang (BPPK Kemenkeu, 2011). Perencanaan sebagai tahapan awal dan penting dalam pengelolaan BMD merupakan komponen yang sangat penting untuk mewujudkan laporan keuangan yang lebih baik (Yusuf, 2015:9). Penelitian Hidayati, et al. (2016) membuktikan bahwa perencanaan berpengaruh signifikan terhadap kualitas laporan keuangan. Hal ini berarti semakin baik perencanaan maka semakin baik pula kualitas laporan keuangan pemerintah daerah.

Penilaian BMD adalah proses kegiatan yang dilakukan oleh penilai untuk memberikan suatu opini atas nilai suatu obyek penilaian pada saat tertentu dalam rangka pengelolaan BMD (PP No 27 Tahun 2014). Penilaian BMD yang baik akan menghasilkan penyajian nilai neraca atas aset pemerintah daerah akan memadai sehingga dapat memberikan kontribusi terhadap peningkatan kualitas laporan keuangan daerah. Penelitian Simamora (2012) dan Anshari (2016) menunjukkan bahwa penilaian aset/barang berpengaruh positif dan signifikan terhadap kualitas laporan keuangan. Artinya apabila dilakukan peningkatan terhadap penilaian aset/barang maka akan meningkatkan kualitas laporang keuangan pada Pemerintah Kota Padang.

Penatausahaan BMD adalah rangkaian kegiatan yang meliputi pembukuan, inventarisasi dan pelaporan BMD sesuai dengan ketentuan yang berlaku (Permendagri No 17 Tahun 2007). Dengan penatausahaan BMD akan dapat diketahui secara pasti nilai kekayaan daerah, status kepemilikan, pemanfaatan serta pemeliharaan terhadap BMD yang dikuasai pemerintah daerah. Sehingga akan menghasilkan sinkronisasi antara laporan keuangan pemerintah daerah dengan laporan BMD. Penelitian Anggareini (2015) dan Febrianti (2016) menunjukkan bahwa penatausahaan berpengaruh positif dan signifikan terhadap kualitas laporan keuangan Pemerintah Daerah. Hal ini menunjukkan bahwa semakin baik penatausahaan aset/barang maka semakin baik kualitas pada laporan keuangan pemerintah daerah.

Pengawasan adalah usaha atau kegiatan untuk mengetahui dan menilai kenyataan yang sebenarnya mengenai pelaksanaan tugas dan/atau kegiatan dibandingkan dengan peraturan perundang-undangan yang berlaku. Pengendalian adalah usaha atau kegiatan untuk menjamin dan mengarahkan agar pekerjaan yang dilaksanakan berjalan sesuai dengan rencana yang telah ditetapkan. Untuk menjamin kelancaran penyelenggaraan dan menjamin tertib administrasi pengelolaan BMD secara efisien dan efektif maka diperlukan fungsi pembinaan, pengawasan, dan pengendalian atas aset/BMD. Hal itu sangat penting untuk memastikan bahwa seluruh mekanisme dan prosedur pengelolaan BMD telah dilakukan 
sesuai dengan peraturan perundang-undangan. Sehingga pengelolaan aset/ barang daerah akan semakin baik maka akan mewujudkan laporan keuangan yang lebih baik dan berkualitas (Yusuf, 2015:9). Penelitian Anshari (2016) juga diperkuat dengan penelitian Hidayati, et al. (2016). menunjukkan bahwa pengawasan dan pengendalian BMD berpengaruh signifikan terhadap kualitas laporan keuangan.

\section{Metode Penelitian}

Penelitian ini merupakan jenis penelitian kuantitatif yang bertujuan memberikan bukti empiris pengaruh perencanaan (X1), penilaian (X2), penatausahaan (X3), pengawasan dan pengendalian (X4) sebagai variabel independen terhadap kualitas laporan keuangan pemerintah daerah sebagai variabel dependen. Teknik analisis yang digunakan adalah analisis regresi linear berganda.

Penelitian ini dilakukan pada Pemerintah Kabupaten Kepulauan Talaud Provinsi Sulawesi Utara. Populasi yang digunakan adalah Pengelola Keuangan dan Barang sejumlah 224 orang yang tersebar di 33 SKPD yang berada di Pemerintah Kabupaten Kepulauan Talaud.

Teknik pengambilan sampel dalam penelitian ini dilakukan secara purpossive sampling. Berdasarkan kriteria yang telah ditetapkan, sampel yang diambil sejumlah 158 orang yang tersebar di 33 SKPD di Kabupaten Kepulauan Talaud. Sampel diambil hanya pada Dinas/Badan/ Sekretariat/Kantor.

Perencanaan diukur dengan dimensi kondisi barang yang ada, kebutuhan barang yang akan datang dan penganggaran dengan menggunakan 11 (sebelas) pernyataan. Penilaian diukur dengan dimensi tujuan penilaian, standar penilaian dan objek penilaian dengan menggunakan 9 (sembilan) pernyataan. Penatausahaan diukur dengan dimensi pembukuan, inventarisasi dan pelaporan, dengan menggunakan 11 (sebelas) pernyataan. Pengawasan dan pengendalian diukur dengan dimensi supervisi, pemantauan, pembagian tugas dan wewenang, audit APIP dengan menggunakan 19 (Sembilan belas) pernyataan. Kualitas laporan keuangan diukur dengan dimensi relevan, andal, dapat dibandingkan, dan dapat dipahami dengan menggunakan 14 (empat belas) pernyataan. Masing-masing item pernyataan tersebut kemudian diukur dengan menggunakan Skala Likert 5 point.

\section{Hasil dan Pembahasan}

Data dalam penelitian ini yaitu data primer yang dikumpulkan dengan cara menyebarkan kuesioner langsung kepada 158 responden yang tersebar pada 33 SKPD di Kabupaten Kepulauan Talaud. Sebanyak 158 kuesioner yang disebarkan, terkumpul sebanyak 142 kuesioner, hal ini disebabkan karena pada saat dikumpul, beberapa kuesioner tidak dikembalikan oleh responden. Dari 142 kuesioner yang dikembalikan, terdapat 3 kuesioner yang tidak dapat digunakan karena tidak diisi dengan lengkap, sehingga kuesioner yang dapat diolah sebanyak 139 kuesioner.

Untuk mendapatkan kualitas data dari suatu instrumen telah dilakukan uji validitas dan reliabilitas. Pengujian validitas dalam penelitian ini menggunakan Pearson Correlation yaitu dengan cara menghitung korelasi antara skor masing-masing butir pernyataan dengan skor total. Jika korelasi antara skor masing-masing butir pernyataan dengan skor total mempunyai tingkat signifikansi $<0,05$, maka butir pernyataan tersebut dinyatakan valid dan sebaliknya. Hasil uji coba menunjukkan bahwa semua item pernyataan untuk variabel perencanaan, penilaian, penatausahan, pengawasan dan pengendalian BMD memiliki kriteria valid dengan nilai signifikansi $<0,05$. Hal ini berarti semua item pernyataan yang digunakan dalam penelitian ini mampu mengungkapkan semua variabel yang diukur pada kuesioner tersebut. 
Pengujian reliabilitas dilakukan menggunakan teknik Cronbach Alpha. Suatu instrumen dapat dikatakan reliabel bila memiliki koefisien keandalan atau Cronbach Alpha $\geq 0,60$. Berdasarkan uji reliabilitas menunjukkan nilai Cronbach's Alpha untuk variabel perencanaan BMD sebesar 0,808; penilaian BMD sebesar 0,842; penatausahaan BMD sebesar 0,799; pengawasan dan pengendalian BMD sebesar 0,916 dan kualitas laporan keuangan pemerintah daerah 0,922. Dengan demikian dapat disimpulkan bahwa pernyataan dalam kuesioner ini reliable karena memiliki nilai Cronbach's Alpha $>0,60$. Hal ini menunjukkan bahwa apabila pernyataan diajukan kembali akan diperoleh jawaban yang relatif sama dengan jawaban sebelumnya.

Uji normalitas dilakukan untuk mengetahui data berdistribusi normal. Uji normalitas dalam penelitian ini dengan menggunakan grafik P-Plot SPSS dan uji normalitas KolmogorovSmirnov. Melalui grafik P-Plot dapat dinilai dari titik-titik penyebaran disekitar garis diagonal apakah searah dan mengikuti garis diagonal, sedangkan pada uji normalitas KolmogorovSmirnov akan dilihat nilai signifikansinya apabila lebih dari 0,05 maka data tersebut berdistribusi normal. Berdasarkan uji normalitas dengan grafik P-Plot SPSS, didapatkan bahwa titik data menyebar di sekitar garis diagonal dan penyebaran titik-titik data searah mengikuti garis diagonal. Berdasarkan uji normalitas Kolmogorov-Smirnov dilihat bahwa nilai asymp.sig (2-tailed) atau signifikansi sebesar 0,189 lebih besar dari 0.05 sehingga dapat disimpulkan bahwa data yang diuji berdistribusi normal. Dengan demikian model regresi telah memenuhi asumsi normalitas.

Pengujian multikolinieritas dilakukan untuk melihat apakah pada model regresi ditemukan adanya korelasi antara variabel independen. Cara mendeteksinya adalah dengan melihat nilai tolerance dan nilai Variance Inflation Factor (VIF). Jika nilai VIF $<10$ dan tolerance $>0,1$ maka variabel independen terbebas dari persoalan multikolinieritas. Hasil uji SPSS menunjukkan bahwa semua nilai tolerance $>0,1$ dan nilai $\mathrm{VIF}<10$. Hasil uji SPSS menunjukkan bahwa semua nilai tolerance $>0,1$ dan nilai $\mathrm{VIF}<10$. Hal ini menunjukkan bahwa semua variabel independen terbebas dari multikolinieritas.

Uji heterokedastisitas dilakukan untuk mengetahui apkah dalam sebuah model regresi terjadi ketidaksamaan varians dari residual suatu pengamatan ke pengamatan lain. Ada tidaknya heteroskedastisitas dapat ditentukan dengan melihat grafik plot antara nilai prediksi variabel terikat dengan residual. Jika grafik plot menunjukkan suatu pola titik yang bergelombang atau melebar kemudian menyempit, maka dapat disimpulkan bahwa telah terjadi heteroskedastisitas. Namun jika tidak ada pola yang jelas, yaitu serat titik-titik menyebar di atas dan di bawah angka 0 pada sumbu $Y$, maka tidak terjadi heteroskedastisitas. Hasil uji menunjukkan bahwa pada scatterplot, titik-titik yang ada tidak membentuk sebuah pola namun menyebar, sehingga dapat disimpulkan bahwa dalam penelitian tidak terjadi heterokedastisitas.

Hasil pengujian asumsi klasik menunjukkan bahwa model regresi yang dipakai telah memenuhi asumsi klasik sehingga dapat dilanjutkan dengan analisis regresi berganda. Model regresi berganda dalam penelitian ini adalah untuk menguji pengaruh perencanaan BMD $\left(\mathrm{X}_{1}\right)$, penilaian BMD $\left(\mathrm{X}_{2}\right)$, penatausahaan $\mathrm{BMD}\left(\mathrm{X}_{3}\right)$ dan pengawasan dan pengendalian $\mathrm{BMD}$ $\left(\mathrm{X}_{4}\right)$, terhadap kualitas laporan keuangan pemerintah daerah $(\mathrm{Y})$. Hasil analisis regresi linear berganda pada tabel 1 berikut. 
Tabel 1. Hasil Regresi Linear Berganda

\begin{tabular}{|c|c|c|c|c|c|c|c|c|}
\hline \multicolumn{7}{|c|}{ Coefficients $^{a}$} & \multirow{2}{*}{\multicolumn{2}{|c|}{$\begin{array}{l}\text { Collinearity } \\
\text { Statistics }\end{array}$}} \\
\hline & \multirow[t]{2}{*}{ Model } & \multicolumn{2}{|c|}{$\begin{array}{l}\text { Unstandardized } \\
\text { Coefficients }\end{array}$} & \multirow{2}{*}{$\begin{array}{c}\text { Standardized } \\
\text { Coefficients }\end{array}$} & \multirow[t]{2}{*}{$\mathrm{t}$} & \multirow[t]{2}{*}{ Sig. } & & \\
\hline & & B & Std. Error & & & & Tolerance & VIP \\
\hline \multirow{5}{*}{1} & (Constant) & 13.530 & 5.880 & & 2.301 & .023 & & \\
\hline & perencanaan & -.064 & .116 & -.045 & -.557 & .578 & .718 & 1.394 \\
\hline & penilaian & .310 & .133 & .222 & 2.336 & .021 & .511 & 1.956 \\
\hline & penatausahaan & .425 & .130 & .281 & 3.261 & .001 & .619 & 1.615 \\
\hline & $\begin{array}{l}\text { Pengawasan dan } \\
\text { pengedalian }\end{array}$ & .243 & .065 & .310 & 3.744 & .000 & .673 & 1.486 \\
\hline
\end{tabular}

Pengujian hipotesis dengan uji $\mathrm{F}$ (Fisher Test) dilakukan untuk menunjukkan apakah semua variabel independen yang digunakan dalam model regresi mempunyai pengaruh yang signifikan secara bersama-sama (simultan) terhadap variabel dependen. Berdasarkan tabel distribusi $F$, nilai $F_{\text {tabel }}=2,43$. Hasil uji $F$ didapatkan $F_{\text {hitung }}=20.834$, hal ini menunjukkan bahwa $F_{\text {hitung }}=20.834>F_{\text {tabel }}=2,43$ maka Ha diterima dan Ho ditolak. Dilihat dari nilai signifikansi menunjukkan bahwa nilai signifikansi adalah $0,000<0,005$ sehingga Ha diterima dan Ho ditolak. Hasil pengujian ini menunjukkan bahwa seluruh variabel independen yaitu perencanaan $\mathrm{BMD}$, penilaian $\mathrm{BMD}$, penatausahaan $\mathrm{BMD}$, pengawasan dan pengendalian BMD secara bersama-sama berpengaruh secara signifikan terhadap variabel dependen yaitu kualitas laporan keuangan pemerintah daerah.

Pengujian hipotesis dengan uji t dilakukan untuk mengetahui besarnya pengaruh masing-masing (parsial) variabel independen secara individual terhadap variabel dependen. Uji $t$ juga dilakukan dengan membandingkan nilai $t_{\text {hitung }}$ dengan nilai $t_{\text {tabel }}$. Nilai $t_{\text {hitung }}$ diperoleh dari hasil perhitungan SPSS sedangkan $t_{\text {tabel }}$ diperoleh dari tabel distribusi $t$ dicari pada $\alpha=5 \%: 2=2,5 \%$ (uji 2 sisi) dengan derajat kebebasan (df) n-k-1 atau 139-4-1 = 134 . Dengan pengujian 2 sisi (signifikansi $=0,025$ ) hasil diperoleh untuk $t_{\text {tabel }}$ sebesar 1,960.

Pengaruh perencanaan BMD terhadap kualitas laporan keuangan pemerintah daerah, nilai $=-0.557<t_{\text {tabel }}=1,960$ dan signifikansi sebesar $0,578>0,05$. Hal ini menunjukkan bahwa $\mathrm{Ha}_{1}$ ditolak dan $\mathrm{Ho}_{1}$ diterima, sehingga terbukti bahwa perencanaan BMD tidak berpengaruh signifikan terhadap kualitas laporan keuangan pemerintah daerah.

Pengaruh penilaian BMD terhadap kualitas laporan keuangan pemerintah daerah, $t_{\text {hitung }}=2.336>t_{\text {tabel }}=1,960$ dan Signifikansi sebesar 0,021 $<0,05$. Hal ini menunjukkan bahwa $\mathrm{Ha}_{2}$ diterima dan $\mathrm{Ho}_{2}$ ditolak, sehingga terbukti bahwa penilaian $\mathrm{BMD}$ berpengaruh signifikan terhadap kualitas laporan keuangan pemerintah daerah.

Pengaruh penatausahaan BMD terhadap kualitas laporan keuangan pemerintah daerah, nilai $t_{\text {hitung }}=3,261>t_{\text {tabel }}=1,960$ dan signifikansi sebesar 0,001 $<0,05$. Hal ini menunjukkan bahwa $\mathrm{Ha}_{3}$ diterima dan $\mathrm{Ho}_{3}$ ditolak, sehingga terbukti bahwa penatausahaan BMD berpengaruh signifikan terhadap kualitas laporan keuangan pemerintah daerah.

Pengaruh pengawasan dan pengendalian BMD terhadap kualitas laporan keuangan pemerintah daerah, $t_{\text {hitung }}=3.744>t_{\text {tabel }}=1,960$ dan signifikan sebesar $0,000<0,05$. Hal ini menunjukkan bahwa $\mathrm{Ha}_{4}$ diterima dan $\mathrm{Ho}_{4}$ ditolak, sehingga terbukti bahwa pengawasan dan pengendalian BMD berpengaruh signifikan terhadap kualitas laporan keuangan pemerintah daerah.

Uji koefisien determinasi dalam regresi linear berganda, untuk regresi dengan lebih dari dua variabel bebas digunakan adjusted $R^{2}$ sebagai koefisien determinasi. Berdasarkan 
hasil uji, nilai adjusted $\mathrm{R}^{2}$ adalah 0,365 yang artinya kualitas laporan keuangan pemerintah daerah sebesar $36,5 \%$ dipengaruhi oleh perencanaan $B M D$, penilaian $B M D$, penatausahaan BMD dan pengawasan dan pengendalian BMD sedangkan sisanya $63,5 \%$ dipengaruhi oleh faktor lain di luar penelitian ini.

\section{Pengaruh perencanaan BMD terhadap kualitas LKPD}

Hasil pengujian hipotesis pertama menunjukkan bahwa nilai koefisien regresi perencanaan BMD adalah 0,064 dengan arah negatif dan $t_{\text {hitung }}=-0,557<t_{\text {tabel }}=1,960$ serta nilai signifikansi sebesar 0,578 > 0,05 menunjukkan bahwa perencanaan BMD berpengaruh negatif dan tidak signifikan secara statistik terhadap kualitas laporan keuangan Pemerintah Daerah Kabupaten Kepulauan Talaud.

Penelitian ini berpendapat bahwa diperolehnya temuan yang berlawanan dengan hipotesis dapat dijelaskan melalui beberapa permasalahan yang terkait dengan proses perencanaan BMD di Kabupaten Kepulauan Talaud sehingga berdampak pada penurunan kualitas laporan keuangan pemerintah daerah. Pertama, proses perencanaan kebutuhan dan pemeliharaan barang SKPD terlihat tiap tahunnya, selalu mengajukan barang yang hampir sama dengan kebutuhan tahun sebelumnya, tanpa terlebih dahulu dilakukan analisis kebutuhan dan skala prioritas pemeliharaan barang. Sehingga ada kekuatiran dari Tim Anggaran dalam mengambil keputusan kebutuhan dan pemeliharaan barang daerah karena kurang percaya terhadap kebenaran pengajuan tersebut. Kedua, masih ada SKPD yang melaksanakan perencanaan barang belum sesuai dengan standar harga. Hal ini akan menurunkan kualitas laporan keuangan karena dianggap belum memenuhi aspek relevan dan andal, karena belum menyajikan informasi aset/barang yang dapat dipakai untuk memprediksi kebutuhan barang dimasa akan datang juga tidak bisa dipakai dalam pengambilan keputusan pengelolaaan BMD.

Menurut Yusuf (2015:9), pengelolaan aset/BMD merupakan komponen yang sangat penting untuk mewujudkan laporan keuangan yang lebih baik/berkualitas. Perencenaan BMD yang merupakan tahapan awal dan penting dalam proses pengelolaan aset/BMD harus dilakukan secara optimal dan efisien.

Hasil penelitian ini tidak mendukung penelitian yang dilakukan Hidayat et al (2016). Hasil penelitiannya menunjukkan bahwa perencanaan BMD berpengaruh signifikan terhadap kualitas laporan keuangan. Demikian juga penelitian Evira (2015), Hasil penelitiannya menunjukkan bahwa perencanaan berpengaruh secara signifikan terhadap kewajaran penyajian aset di laporan keuangan pemerintah daerah.

\section{Pengaruh penilaian BMD terhadap kualitas LKPD}

Hasil pengujian hipotesis kedua menunjukkan bahwa variabel penilaian barang milik daerah, $t_{\text {hitung }}=2,336>t_{\text {tabel }}=1,960$ serta nilai signifikansi sebesar $0,021<0,05$ sehingga penilaian BMD berpengaruh signifikan terhadap kualitas laporan keuangan pemerintah daerah. Nilai koefisien regresi penilaian BMD sebesar 0,310 dan bernilai positif menunjukkan jika penilaian BMD semakin baik akan meningkatkan kualitas laporan keuangan pemerintah daerah Kabupaten Kepulauan Talaud.

Menurut Kementerian Keuangan (2013), kegiatan penilaian dilakukan dalam rangka pengelolaan BMD yang merupakan implementasi tindakan untuk mendukung kepastian nilai, yaitu adanya ketepatan jumlah dan nilai barang dalam rangka optimalisasi pemanfaatan dan pemindatanganan BMD serta penyusunan neraca pemerintah daerah. Selanjutnya, Bastian (2006) menjelaskan bahwa neraca awal memiliki peran yang sangat penting karena akan terbawa terus dan dipakai sebagai dasar dalam menentukan posisi keuangan pemerintah serta akan memberikan informasi penting kepada manajemen pemerintah dan stakeholder 
tentang posisi atau keadaan dari kekayaan atau aset daerah beserta liabilitas dan ekuitas dananya pada tanggal tertentu. Sehingga penilaian barang yang merupakan tahapan pengelolaan BMD, sangat penting untuk mewujudkan laporan keuangan yang lebih baik (Yusuf 2015:9). Karena hasil penilaian inilah yang akan dijadikan dasar untuk melakukan perbaikan pengelolaan aset/barang daerah sehingga dapat dimanfaatkan secara maksimal.

Hal ini mengkonfirmasi asumsi filosofis dari teori kepatuhan yang menjelaskan bahwa seorang individu cenderung mematuhi hukum yang mereka anggap sesuai dan konsisten dengan norma-norma internal mereka. Dalam proses pengelolaaan BMD khususnya penilaian BMD harus memenuhi kepatuhan terhadap peraturan perundang-undangan yang berlaku.

Hasil penelitian ini mendukung penelitian yang dilakukan Anshari (2016) dan Simamora (2012) yang membuktikan bahwa penilaian aset/barang mempengaruhi kualitas laporan keuangan, juga penelitian Ristiasiri (2014) yang membuktikan bahwa penilaian aset tetap berpengaruh terhadap persepsi penyajian nilai wajar neraca Pemerintah Kota Banjarbaru.

Hasil penelitian ini tidak mendukung penelitian Hidayati, et al. (2016), hasil penelitiaannya menunjukkan bahwa pelaksanaan BMD yang salah satu faktornya penilaian BMD tidak terbukti berpengaruh signifikan terhadap kualitas laporan keuangan. Juga tidak mendukung penelitian Wiraputri (2012) pada Pemerintah Kabupaten/Kota Ciayu Majakuning, Subang, Karawang dan Purwakarta yang membuktikan bahwa pengelolaan BMD berpengaruh positif namun tidak signifikan terhadap kualitas laporan keuangan.

\section{Pengaruh Penatausahaan BMD terhadap Kualitas LKPD}

Hasil pengujian hipotesis ketiga menunjukkan bahwa pada variabel penatausahaan $\mathrm{BMD}, \mathrm{t}_{\text {hitung }}=3,261>\mathrm{t}_{\text {tabel }}=1,960$ dan nilai signifikansi sebesar $0,001<0,05$ sehingga penatausahaan BMD berpengaruh signifikan terhadap kualitas laporan keuangan pemerintah daerah. Nilai koefisien regresi sebesar 0,425 dan bernilai positif menunjukkan jika pelaksanaan penatausahaan BMD semakin baik akan meningkatkan kualitas laporan keuangan Pemerintah Daerah Kabupaten Kepulauan Talaud.

Menurut Kementerian Keuangan (2013), Penatausahaan/pencatatan barang daerah pada SKPD sangat penting dikarenakan catatan tersebut dijadikan objek audit oleh BPK dalam meyakini penyajian laporan keuangan SKPD dan Pemerintah Daerah. Dengan penatausahaan secara tertib, maka akan dihasilkan angka-angka yang tepat dan akurat yang berdampak pada tersedianya database yang memadai dalam menyusun perencanaan kebutuhan dan penganggaran serta akan menghasilkan laporan aset dineraca dengan angka yang tepat dan akurat sehingga akan meningkatkan kualitas laporan keuangan yang lebih baik. Selanjutnya Yusuf (2015:27) menjelaskan bahwa neraca daerah yang merupakan bagian dari komponen laporan keuangan akan lengkap dan dapat dipercaya jika penatausahaan aset antara fisik aset, dokumen pemilikan, dan penatausahaan dalam buku inventaris mempunyai kesesuaian. Dengan adanya alur penatausahaan yang sistematis maka tingkat kepercayaan terhadap proses penatausahaan akan selalu dapat dipercaya siapapun yang membaca laporan keuangan tersebut. Selain itu, BPK RI selaku auditor akan lebih mudah menelusuri aset dengan kriteria yang telah ditetapkan dalam standar akuntansi sehingga BPK RI tidak akan ragu dalam menilai tingkat kewajaran keberadaan aset baik secara administrasi ataupun secara fisik.

Hal ini mengkonfirmasi asumsi filosofis dari teori kepatuhan yang menjelaskan bahwa seorang individu cenderung mematuhi hukum yang mereka anggap sesuai dan konsisten dengan norma-norma internal mereka. Dalam proses pengelolaaan BMD khususnya dalam 
proses penatausahaan BMD harus memenuhi kepatuhan terhadap peraturan perundangundangan yang berlaku.

Hasil penelitian ini mendukung penelitian yang dilakukan Anggareini (2015) dan Febrianti (2016) yang meneliti tentang pengaruh penatausahaan aset tetap terhadap kualitas laporan keuangan pemerintah daerah. Hasil penelitian menunjukkan bahwa penatausahaan berpengaruh positif dan signifikan terhadap kualitas laporan keuangan pemerintah daerah.

Hasil penelitian ini tidak mendukung penelitian Hidayati, et al. (2016), hasil penelitiaannya menunjukkan bahwa pelaksanaan BMD yang salah satunya penatausahaan tidak terbukti berpengaruh signifikan terhadap kualitas laporan keuangan.

\section{Pengaruh Pengawasan dan Pengendalian BMD terhadap Kualitas LKPD.}

Hasil pengujian hipotesis keempat menunjukkan bahwa pada variabel pengawasan dan pengendalian $B M D, t_{\text {hitung }}=3,744>t_{\text {tabel }}=1,960$ dan nilai signifikansi sebesar $0,000<0,05$ sehingga pengawasan dan pengendalian BMD berpengaruh signifikan terhadap kualitas laporan keuangan pemerintah daerah. Nilai koefisien regresi pengawasan dan pengendalian BMD sebesar 0,243 menunjukkan jika pengawasan dan pengendalian BMD semakin baik akan meningkatkan kualitas laporan keuangan Pemerintah Daerah Kabupaten Kepulauan Talaud.

Menurut Kementerian Keuangan (2013), untuk menjamin kelancaran penyelenggaraan dan menjamin tertib administrasi pengelolaan BMD secara efisien dan efektif maka diperlukan fungsi pengawasan, dan pengendalian atas aset/BMD. Selanjutnya Mardiasmo (2004:78) menegaskan bahwa pengawasan yang ketat perlu dilakukan sejak tahap perencanaan hingga penghapusan aset. Hal itu sangat penting untuk memastikan bahwa seluruh mekanisme dan prosedur pengelolaan BMD telah dilakukan sesuai dengan peraturan perundang-undangan. Sehingga pengelolaan aset/barang daerah semakin baik maka akan mewujudkan laporan keuangan yang lebik baik dan berkualitas (Yusuf, 2015:9).

Hal ini mengkonfirmasi asumsi filosofis dari teori atribusi yang menjelaskan bahwa tindakan seorang pemimpin maupun orang yang diberikan wewenang dipengaruhi oleh atribut penyebab (Green dan Mitchell dikutip oleh Adelin, 2013). Tindakan kecurangan dapat dipengaruhi adanya sistem pengendalian internal dan monitoring oleh atasan, sehingga dengan adanya pengendalian internal maka tindakan tidak etis akan berkurang. Jika keefektifan pengendalian internal tinggi maka perilaku tidak etis akan menurun. Dalam proses pengelolaan BMD diperlukan pengawasan dan pengendalian terhadap pelaksanaan pengelolaan BMD untuk menjamin kelancaran penyelenggaraan dan menjamin tertib administrasi pengelolaan BMD secara efisien dan efektif, serta memastikan bahwa seluruh mekanisme dan prosedur pengelolaan BMD telah dilakukan sesuai dengan peraturan perundang-undangan.

Hasil penelitian ini mendukung penelitian yang dilakukan Hidayat et al. (2016) dan Anshari (2016) yang meneliti tentang pengaruh pengelolaan BMD terhadap kualitas laporan keuangan pemerintah daerah. Hasil penelitian menunjukkan pengawasan dan pengendalian berpengaruh positif dan signifikan terhadap kualitas laporan keuangan pemerintah daerah.

\section{Kesimpulan dan Saran}

Hasil penelitian menunjukkan bahwa secara parsial perencanaan BMD berpengaruh negatif dan tidak signifikan secara statistik terhadap kualitas laporan keuangan Pemerintah Daerah Kabupaten Kepulauan Talaud sedangkan penilaian, penatausahan, pengawasan dan pengendalian BMD berpengaruh positif dan signifikan terhadap kualitas laporan keuangan Pemerintah Daerah Kabupaten Kepulauan Talaud. Pengujian secara simultan perencanaan, 
penilaian, penatausahaan, pengawasan dan pengendalian BMD berpengaruh positif dan signifikan terhadap kualitas laporan keuangan Pemerintah Daerah Kabupaten Kepulauan Talaud.

Saran yang dapat diberikan dalam penelitian ini agar Pemerintah Kabupaten Kepulauan Talaud, 1) perlu melakukan peningkatan kemampuan sumber daya aparatur pengelolah BMD dengan melakukan pendidikan dan pelatihan, 2) melakukan analisis kebutuhan dan skala prioritas pemeliharaan BMD sebelum melakukan perencanaan BMD, 3) melakukan kegiatan sensus BMD secara komprehensif mulai dari unit kerja/SKPD untuk mendapatkan data barang/aset yang benar dan dapat dipertanggungjawabkan serta nilai aset yang akurat (up to date), 4) lebih meningkatkan kinerja pengawasan dan pengendalian terhadap pengelolaan BMD serta 5) perlu adanya regulasi khusus tentang sistem dan prosedur pengelolaan BMD.

\section{Daftar Pustaka}

Adelin, Vani \& Eka Fauzihardani. 2013. Pengaruh Pengendalian Internal, Ketaaatan pada Aturan Akuntansi dan Kecenderungan Kecurangan Terhadap Perilaku Tidak Etis. WRA, Vol. 1, No. 2.

Anshari, Efrizal Syofyan. 2016. Pengaruh Pengelolaan Barang Milik Daerah Terhadap Kualitas Laporan Keuangan Pemerintah Kota Padang. Jurnal riset manajemen bisnis dan public, Vol. 4 No. 1.

Anggareini, Ayang Putri Septiayu. 2015. Pengaruh penatausahaan Barang Milik Negara terhadap kualitas laporan keuangan pada Kantor kementrian agama kota probolinggo. Tesis. Universitas Islam Negeri Maulana Malik Ibrahim Malang.

Badan Pemeriksa Keuangan, 2015. Ikhtisar Hasil Pemeriksaan Semester II Tahun 2015.

Badan Pemeriksa Keuangan, 2016. Ikhtisar Hasil Pemeriksaan Semester I Tahun 2016.

Bastian, Indra. 2009. Akuntansi Sektor Publik Suatu Pengantar Edisi Ketiga. Jakarta: Erlangga

BPPK Kemenkeu Republik Indonesia. 2011. Pembinaan, Pengawasan, dan Pengendalian Barang Milik Negara. Jakarta.

Evira. 2015. Manajemen aset daerah terhadap Kewajaran laporan keuangan pemerintah daerah menurut pp no. 71 tahun 2010 dan psap no. 07 (studi kasus pada pemerintah kabupaten Grobogan). Tesis. Universitas Sebelas Maret Surakarta

Febrianti, Sukma. 2016. Pengaruh Penatausahaan Aset Tetap Terhadap Kualitas Laporan Keuangan Pemerintah Kabupaten Kubu Raya. Jurnal Ekonomi Manajemen Vol. 10 No. 1

Ferdianus, 2013. Analisis penatausahaan aset tetap untuk menghasilkan data yang dipercaya dalam laporan barang milik daerah (studi pada pemerintah provinsi maluku). Tesis. Universitas Gajah Mada.

Hidayati, et al. 2016. Pengaruh siklus pengelolaan barang milik daerah terhadap kualitas laporan keuangan *(studi empiris pada pemerintah kabupaten solok selatan). Jurnal Akuntansi vol 8, No.1

Kementrian Keuangan RI, 2013. Modul Pelatihan Pengelolaan Barang Milik Daerah. Edisi Tahun 2013.

Mahmudi, 2015. Analisis Laporan Keuangan Pemerintah Daerah Edisi ketiga, Yogyakarta: UPP STIM YPKN.

Mardiasmo. 2009. Akuntansi sektor publik. Edisi keempat. Yogyakarta : Andi.

PP RI Nomor 71 Tahun 2010 tentang Standar Akuntansi Pemerintah.

PP RI Nomor 27 Tahun 2014 tentang Pengelolaan Barang Milik Negara.

Permendagri Nomor 17 Tahun 2007 tentang Pedoman Teknis Pengelolaan Barang Milik Daerah 
Ristiasiri, Ratih. 2014. Pengaruh Inventarisasi Dan Penilaian Aset Tetap/Barang Milik Daerah Terhadap Persepsi Penyajian Nilai Wajar Neraca Di Pemerintah Kota Banjarbaru. Tesis. Universitas Gajah Mada.

Simamora, Rudianto. 2012. Faktor-faktor yang mempengaruhi pengelolaan aset pasca pemekaran wilayah dan pengaruhnya terhadap kualitas laporan keuangan Pemerintah di Kab. Tapanuli Selatan. Tesis.

Wiraputri, Maya Maulida (2012). Pengaruh Pengelolaan Barang Milik Daerah Terhadap Akuntabilitas dengan Kualitas Laporan Keuangan sebagai Variabel Intervening (Studi Kasus pada Pemerintah Kabupaten/Kota Ciayumajakuning, Subang, Karawang dan Purwakarta). Bandung.

Wungow, J. Fiesgrald. 2016. Pengaruh tingkat pendidikan, masa kerja, pelatihan dan jabatan terhadap kualitas laporan keuangan pemerintah Kabupaten Minahasa Selatan. Tesis.

Yusuf, M. 2015. 8 Langkah Pengelolaan Aset Daerah Menuju Pengelolaan Keuangan Daerah Terbaik. Jakarta: Salemba Empat. 